\title{
TRADE FACILITATION THROUGH LOGISTICS PERFORMANCE: THE ENABLING ROLE OF NATIONAL GOVERNMENT
}

\author{
JAN H. HAVENGA \\ janh@sun.ac.za \\ Centre for Supply Chain Management, Department of Logistics \\ University of Stellenbosch
}

\begin{abstract}
Despite two decades of visionary policies, problems within South Africa's freight logistics system remain. Logistics costs are high, the current road and rail solutions will be unable to meet long-term demand for freight transport sustainably, and rural economies still do not have efficient access to the corridor transport network. This article postulates that one of the core reasons for the state of affairs is the inability of government to enable an optimally functioning freight logistics system. The main challenges faced by government are identified and an intervention is proposed to develop an overarching framework and implementation plan to address South Africa's long-term freight logistics needs.
\end{abstract}

\section{INTRODUCTION}

The World Bank's Logistics Performance Index (2010: III) indicates that 'countries at the same level of per capita income with the best logistics performance experience additional growth of $1 \%$ in Gross Domestic Product (GDP) and 2\% in trade'. Improving logistics performance has therefore become a major policy objective due to its beneficial impact on the economy. Whether or not a successful logistics-trade cycle is created will however ultimately depend upon the extent and pace of government measures to liberalise the supply of logistics (De Sousa \& Findlay, 2007: 245), including appropriate infrastructure investments (World Bank, 2010: 23).

Globally, international trade as a percentage of GDP has grown exponentially and periods of stagnation have only been experienced during major upheavals such as the Second World War (refer to Table 1). 
Table 1: Global exports as percentage of GDP (1820 to 1973 from Oosterhaven \& Rietveld, 2005: 35; 1998 and 2008 from Trading Economics, 2011)

\begin{tabular}{|c|c|}
\hline Year & Exports as \% of world GDP \\
\hline 1820 & 1 \\
\hline 1870 & 5 \\
\hline 1913 & 8 \\
\hline 1929 & 9 \\
\hline 1950 & 6 \\
\hline 1973 & 11 \\
\hline 1998 & 33 \\
\hline 2008 & 50 \\
\hline
\end{tabular}

In South Africa, trade and logistics policies were employed during the twentieth century to support the government's political imperatives. The South African economy has since shifted from a primarily inward-focused economy which relied on import substitution, with a heavy dependence on primary product exports during the apartheid years, to a manufacturingand service-based economy with an export-focused strategy (Jenkins, 2001; Edwards, 2006 and 2008; Theron, Godfrey \& Visser, 2007).

Unfortunately, the process of addressing South Africa's logistics challenges has not made similar macroeconomic progress since the advent of democracy in 1994. At 13.5\%, South Africa's logistics cost as a percentage of GDP remains high in comparison with that of developed countries - 7.5\% in Europe in 2009 (Wilson, 2010) and 8.3\% in the USA in 2010 (Wilson, 2011) - while road transport is capturing long-haul freight transport growth (refer to Table 2). While South Africa is rated as a logistics over-performer in the Logistics Performance Index (LPI) (World Bank, 2010) relative to its income per capita - and performance remained relatively constant when comparing the absolute scores between the 2007 and 2010 World Bank surveys - the country's overall LPI ranking dropped from 24 to 28, and in all the detail measurements the ranking also dropped. This provides an indication that other countries are improving their logistics competencies faster than South Africa (Wesgro, 2010). Given the significant corridor tonkilometre (tonkm) growth of 134\% forecast between 2009 and 2040 (Havenga, Simpson \& Fourie, 2011), the status quo will not be sustainable. 
Table 2: Key indicators: South Africa's national logistics system - logistics cost data (Havenga, Pienaar \& Simpson, 2011); tonkm data (Havenga, Simpson \& Fourie, 2011)

\begin{tabular}{|l|l|l|}
\hline \multicolumn{2}{|l|}{$\mathbf{2 0 0 3}$} & $\mathbf{2 0 0 9}$ \\
\hline Change in key indicators: & $15.2 \%$ & $13.5 \%$ \\
\hline Logistics cost as \% of GDP* & $19.7 \%$ & $16.0 \%$ \\
\hline Rail corridor tonkm market share & $80.3 \%$ & $84.0 \%$ \\
\hline Road corridor tonkm market share & \multicolumn{2}{|c|}{$+32.7 \%$} \\
\hline Growth in corridor tonkm between 2003 and 2009: \\
\hline Total corridor tonkm & $+7.7 \%$ \\
\hline Rail corridor tonkm & $+38.8 \%$ \\
\hline Road corridor tonkm
\end{tabular}

*drop attributable to reduction in interest rate and fall in oil prices, not to logistics efficiency

The growth in road transport is clearly highlighted by the exponential rise in South Africa's truck fleet. The road truck fleet doubled between 1990 (deregulation) and 2010, from an already high base, while the size of the rail wagon fleet declined by almost 35\%, and the locomotive fleet declined by $40 \%$ (Figure 1). This was compounded by the considerable ageing of the rail fleet (in 2002, it was on average $40 \%$ older than fleets in the USA), making it less suitable for changing market needs and resulting in it being almost impossible for the railway to attract or retain corridor transport, and impossible for South Africa to exploit the density advantage of the corridors.

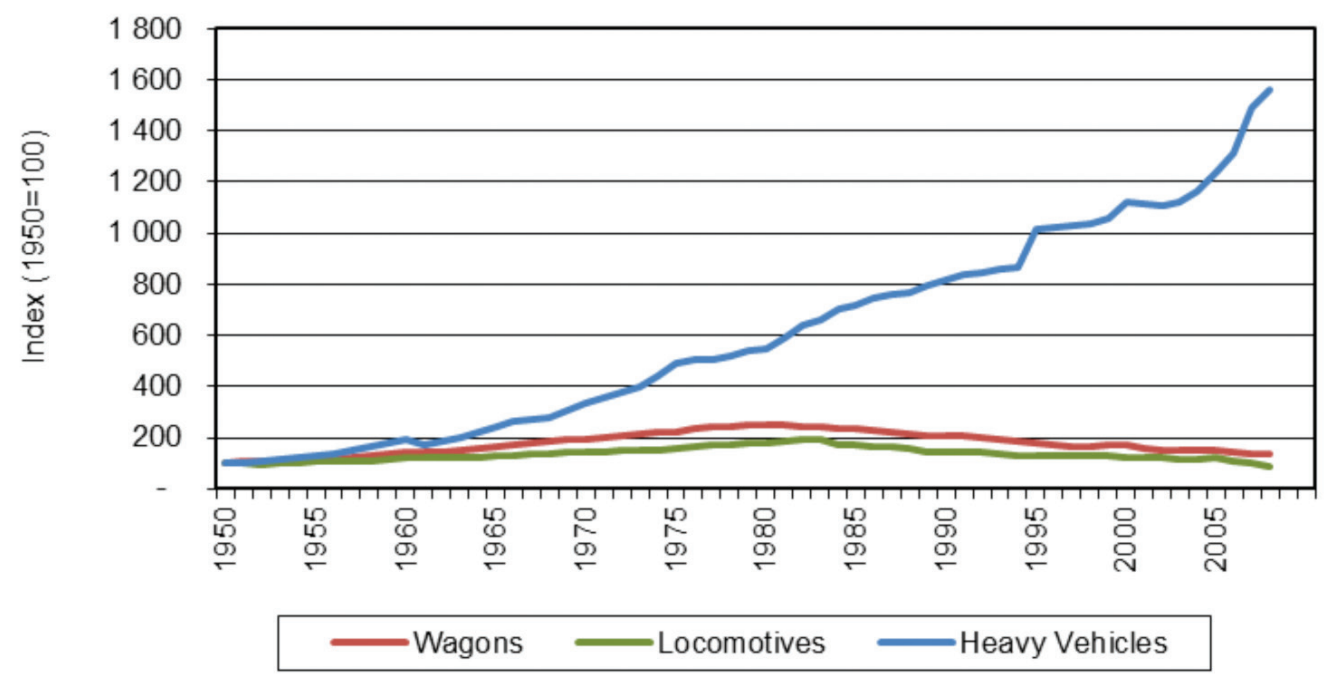

Figure 1: Growth in heavy vehicle population (eNatis, 2011) compared to rail wagons and locomotives (Transnet Freight Rail, 2011)

It was inevitable that road hauliers would serve the growing market demand for transport due to the lack of an efficient, integrated long-haul road-rail solution. This does however 
show a myopic macroeconomic consideration for infrastructure and externality costs of road versus intermodal solutions. The state of affairs can be linked inter alia to the challenges experienced in the implementation of national freight logistics policies.

The purpose of this article is to identify these challenges that hamper the role that government should play in an optimally functioning logistics system, and on proposing a way forward to overcome these challenges. This is informed by the international experience in trade facilitation initiatives as well as by South Africa's inter-related trade and logistics environment during the twentieth century.

\section{RESEARCH APPROACH}

The review of the evolution of trade and logistics policy and the analysis of trade flows were desktop driven. The statistics on South Africa's logistics industry were drawn from a comprehensive set of models developed by the Centre for Supply Chain Management at the University of Stellenbosch - see Havenga (2007 and 2010) for a detailed overview of these models. A qualitative assessment of the implementation status of freight logistics policy as well as a stakeholder response to the trade and logistics policy environment were gathered by the author over a period of 18 months, through independent research projects, presentations at numerous local and international forums, and both formal and informal discussions with senior stakeholders. The discussion is a synthesis of the desktop research, modelling results and qualitative assessments, culminating in recommendations for national government to enable logistics performance.

\section{THE RELATIONSHIP BETWEEN LOGISTICS SECTOR PERFORMANCE AND TRADE FACILITATION - INTERNATIONAL EXPERIENCE}

Trade facilitation as a concept gained prominence at the first ministerial meeting of the World Trade Organisation (WTO) (held in Singapore in December 1996) where it was agreed to form a working group on trade facilitation (WTO Ministerial, 1996). This was brought about by the experience that, once formal trade barriers (such as tariffs and quantitative restrictions) were reduced, other issues restricting trade surfaced (such as bureaucratic customs procedures causing border delays). After several years of exploratory work, the trade facilitation theme was included in the 2004 Doha Development Agenda, with the intent of examining 'how procedures and controls governing the movement of goods across national borders can be improved to reduce costs and burdens'. The ultimate goal is to allow trade flows to be as efficient as possible (WTO, 2011a and 2011b). The concept has evolved to encompass all measures that ease trade transactions and lead to time and cost reductions in the supply chain (UNCTAD, 2006). Trade facilitation measures therefore encompass two dimensions: 'hard' infrastructure (e.g. highways, railroads and ports) and 'soft' infrastructure 
(e.g. transparency, customs efficiency and institutional reforms) (Portugal-Perez \& Wilson, 2009). A number of studies have been conducted highlighting the potential benefits of such trade facilitation interventions.

Korinek and Sourdin (2011) illustrate the strong impact of logistics quality on trade using indicators such as the World Economic Forum's Enabling Trade Index (ETI) - constructed to measure the institutions, policies and services facilitating the free flow of goods across borders; and the World Bank's Logistics Performance Index (LPI) - a survey of global freight forwarders and express carriers' scoring customs, infrastructure, international shipments, logistics competence, tracking and tracing, and timeliness. Specifically, a 10\% improvement in a typical importing ETI is associated with an increase in trade of $19 \%$ on average, while a $10 \%$ improvement in the index in the exporting country is associated with increased trade of $36 \%$, ceteris paribus. Similarly, for every $10 \%$ increase in the LPI of a typical exporter, bilateral imports increase by more than $69 \%$ on average, while for every $10 \%$ increase in the LPI of a typical importing country, bilateral imports increase by $54 \%$ on average.

According to Weerahewa (2009) significant trade gains can be achieved by reducing inefficiencies at the borders in South Asia. His research showed that improving trade variables (such as logistics costs and time delays) in South Asian countries up to the average values of the best performers in South Asia (Pakistan is the least cost country, while India has the best LPI), could bring down trade costs by over $17 \%$ (increasing the value of agricultural trade by $18 \%$ ) and improve LPIs by 0.72 points (increasing the value of agricultural trade by $27 \%$ ).

Wilson, Mann and Otsuki (2003) define and measure trade facilitation using four broad indicators, namely port efficiency, the customs environment, the regulatory environment, and electronic-business usage. In a study on Asia Pacific Economic Cooperation (APEC) members, they conclude that if members with below-average scores on these indicators improve performance halfway to the average for all members, intra-APEC trade flows could grow by $21 \%$ ( $\$ 254$ billion), an increase of $4.3 \%$ in the average APEC per capita GDP.

Portugal-Perez and Wilson (2009) show that increasing South Africa's capacity in trade facilitation half-way to the high-income country LPI average would increase trade by an amount equivalent to the effect of South Africa's trading partners' decreasing their tariffs on imports by approximately $19 \%$.

These studies highlight that significant benefits can still be realised by improving trade facilitation measures. Since trade transaction costs are associated with interactions among multiple layers of transport, infrastructure, policy and geography (often involving several countries), trade facilitation efforts targeted at a single point in the supply chain can be easily impeded and is the reason why isolated infrastructure investments in, for example, 
sub-Saharan Africa does not necessarily lead to significant reduction in logistics costs (Christ \& Ferrantino, 2011).

According to the United Nations (UNCTAD, 2006), recognising that trade facilitation measures are a public good, and that governments need to establish and support the national facilitation bodies with balanced private and public sector participation, is therefore critical for success. These bodies should be formal, permanent institutions that develop procedural and policy solutions to customs, trade and logistics challenges as they are in the position to identify national trade-inhibiting issues and capacity-building needs. Members of such an institution should encompass the whole supply chain, including manufacturers, importers, exporters, logistics service providers, banks, financial and insurance companies and government officials from trade and transport ministries (UNCTAD, 2006).

The private sector has an important role to play in this process through increased collaboration between supply chain members to, inter alia, 1) ensure pro-active cohesive industry input into national trade facilitation measures and resulting policies; 2) provide industry expertise to the national facilitation body; 3) partner with government for funding of trade facilitation reform; and 4) drive implementation of reform measures through the supply chain (Musonda, 2005; UNCTAD 2010; Isemede, 2011).

Successful trade facilitation bodies in developed countries, such as the United Kingdom and Sweden, provide insight into the key success factors of such entities, including:

- political commitment from national government to establish and support a trade facilitation committee as a national forum for promoting trade facilitation measures

- chairmanship by a 'champion' with a vision supported by advisory committees, a steering committee and working groups to ensure focus and continuity

- staff training, awareness raising and publicity campaigns at the national and stakeholder levels to promote consistency and subsequent effectiveness

- recruitment of experienced professionals to lend independence to the body

- finance and sustaining mechanisms to be addressed upfront and public funds to constitute the basic financing source (in developed countries most of these bodies are financed by government, with voluntary time and expertise contributions by the private sector); financial (and technical) assistance from international agencies and donors to be sought

- collaboration between private and public sectors and the creation of a sense of ownership among stakeholders

- to ensure the implementation of reform proposals, relevant ministries need to be represented by officials with decision-making powers who can facilitate implementation 
The lead agency could either be from the public or the private sector, although international experience has shown that most entities originate in government and some are later spun off. It is however important for success that the body is established by decree or within a legal framework (UNCTAD, 2006).

Ikenson (2008) also confirms that trade facilitation must play a central role in any government's attempt to achieve an optimal business environment and policymakers should focus their efforts on removing frictions from local supply chains. It is therefore imperative to address the obstacles that the South African government face in this regard. To provide context for the status quo, it is important to understand the evolution of trade and logistics policy in South Africa during the last century, as described in the next section.

\section{EVOLUTION OF TRADE AND LOGISTICS POLICY IN SOUTH AFRICA}

In the case of South Africa, the potential of logistics to facilitate specific trade and economic objectives was well understood during most of the twentieth century, albeit with a narrow political goal in mind - the transport industry was 'employed' to enable the implementation of government's politico-economic objectives. In the next section an overview of this interconnected evolution of South Africa's trade and logistics policy is provided.

A comparison between GDP and trade trends for South Africa is provided in Figure 2. The key periods in South Africa's trade policy approach are also shown on the graph. Total exports from South Africa showed significant growth up to 1972, then fluctuated around those levels until 1987 (during which time global trade as a percentage of GDP doubled), after which exports started another upward trajectory that is continuing. The import substitution policies of the 1970s and 1980s are evident in the drastic reduction in imports, while the more recent liberalisation in the 1990s played a very important role in stimulating imports. This suggests that import growth could accelerate even further under bilateral trade liberalisation as investment increases, moving the economy to a more rapid growth path (gross fixed investment is about $50 \%$ more import-intensive than consumption expenditure) (Edwards \& Lawrence, 2006). 


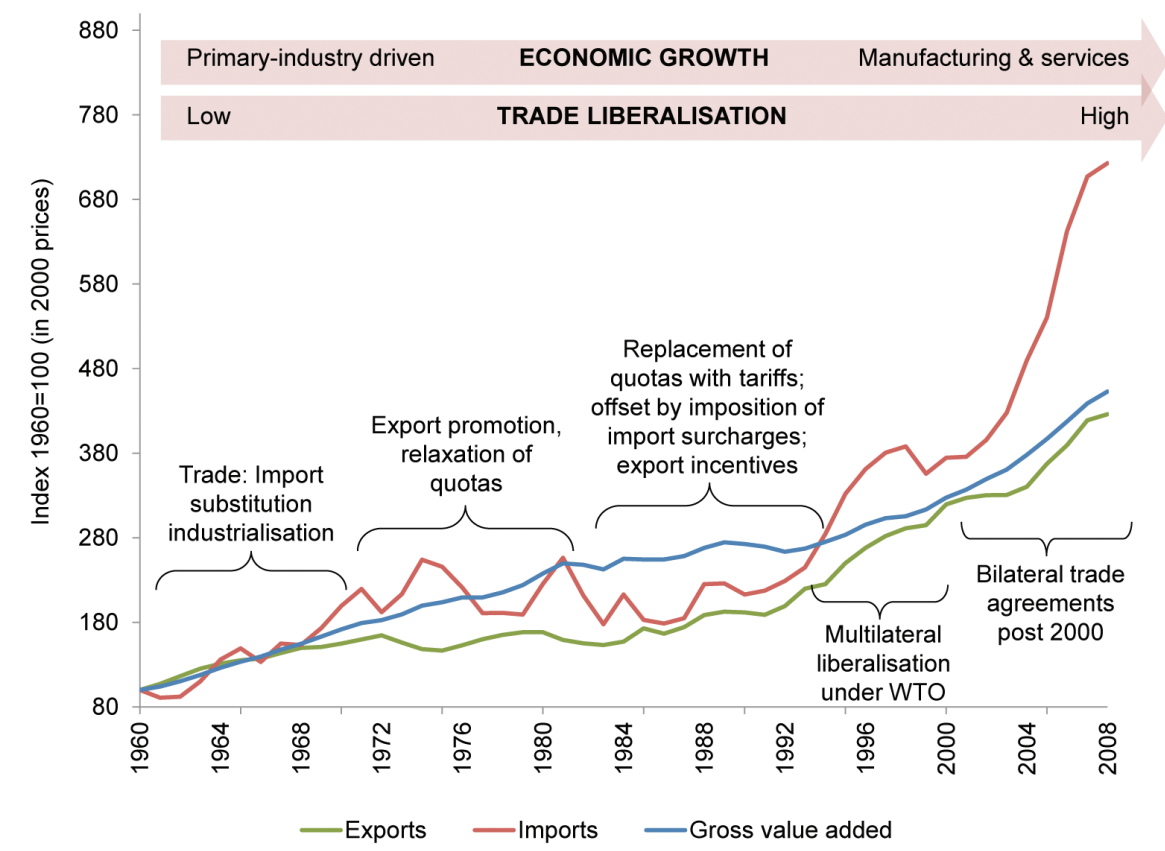

Figure 2: South Africa's GDP, export and import growth since 1960 compared with shifts in trade policy (developed from SARB, 2009; Edwards, 2008)

As mentioned earlier, regulation in the freight logistics industry mirrored trade policies shifting from heavy regulation for the majority of the twentieth century (to support the development of primary industries and the nationalist agenda) towards deregulation in the late 1980s (Stander \& Pienaar, 2005). Figure 3 illustrates the evolution of South Africa's freight transport policy since the mid-1970s. The major challenge is that while the vision for optimising logistics and integrating freight transport services has made significant progress, implementation has been lacking, as is evidenced by the fact that the key issues identified by De Villiers (1986) have still not been adequately resolved.

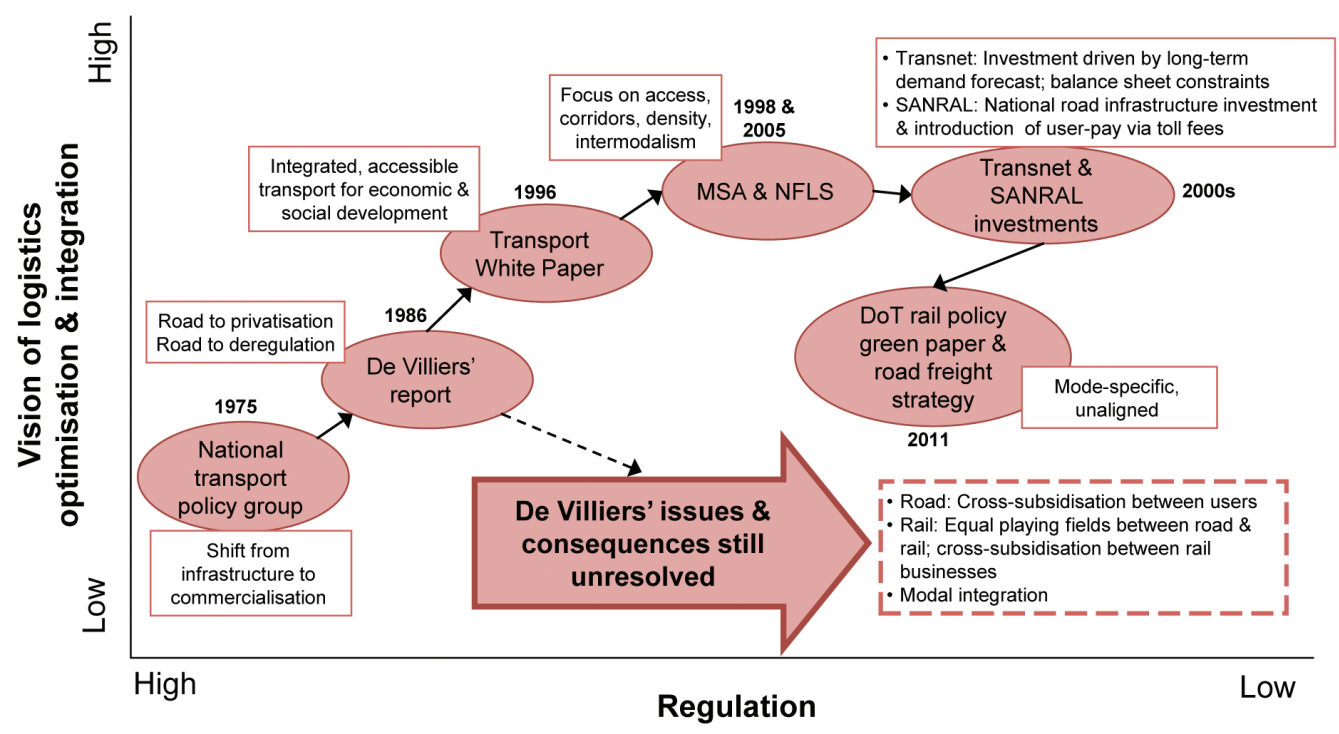

Figure 3: Evolution of South Africa's freight transport policy since the mid-1970s (author's own analysis) 
In 1998, the Moving South Africa (MSA) project was designed to produce a data-driven programme for strategic action that extended the short- to medium-term policy formulation documented in the 1996 White Paper on National Transport Policy (DoT, 1996) into a longterm strategic formulation embodying the sets of trade-offs and choices necessary to realise the White Paper vision of an integrated land freight transport system that would meet certain economic and social ideals (DoT, 1998). However, by 2005 the growth of freight traffic had surpassed most of the 20-year growth forecasts made by MSA - at least 14 years before they were expected (DoT, 2005:ii). The significant pressure placed on the freight system to service this (unforeseen) growth in demand over the short-term placed the critical transformation of the system, as identified in MSA, on the backburner. In 2005, the Department of Transport (DoT) released the National Freight Logistics Strategy (NFLS), building on the White Paper on National Transport Policy and the MSA strategy (DoT, 2005). The MSA stopped short of making firm recommendations on institutional options for the freight system going forward; the NFLS therefore placed a significant focus on institutional restructuring and economic regulation.

The author's interpretation of the key implementation elements of the NFLS and the MSA is summarised in Table 3, with a qualitative indication of the progress in implementing each of these elements. The ranking is based on the results of the research conducted over the past 18 months, and supported by ministerial statements reported in the media (such as Creamer, 2011a; Naidoo, 2011; Smith, 2011; Venter, 2011).

Table 3: Key implementation elements identified by the MSA and the NFLS (based on DoT, 1998 and 2005); and a view on the implementation status (author's own analysis based on research conducted)

\begin{tabular}{|c|c|}
\hline Implementation element & Status* \\
\hline \multicolumn{2}{|l|}{ Institutional and regulatory: } \\
\hline $\begin{array}{l}\text { - Institutional reform to create a new public-private sector balance and a new regulatory } \\
\text { structure to ensure economic efficiency }\end{array}$ & 2 \\
\hline $\begin{array}{l}\text { - Establishment of efficient public-private platforms to facilitate the anticipated public- } \\
\text { private sector balance }\end{array}$ & 2 \\
\hline $\begin{array}{l}\text { - Contributions to the trade facilitation process at all borders and interfaces, thus helping } \\
\text { ports and land transport entities (whether public or private) to act as creative partners in } \\
\text { international trade development }\end{array}$ & 2 \\
\hline \multicolumn{2}{|l|}{ System sustainability and competitiveness to lower the cost of doing business in South Africa: } \\
\hline - Infrastructure investment and maintenance (incl. operational efficiencies) & 3 \\
\hline $\begin{array}{l}\text { For the public sector to own and provide financing for strategic or common user } \\
\text { infrastructure components and to pave the way for increased private financing of facilities }\end{array}$ & 2 \\
\hline o For the private sector to provide superstructure and/or operations investment & 3 \\
\hline - Densification through corridor development (implying integration), facilitated by logistics hubs & 2 \\
\hline - Effective use of the different modes within the transport system & 2 \\
\hline $\begin{array}{l}\text { Enabling the development of the } 2 \text { nd economy through seamless movement of cargo } \\
\text { between } 1 \text { st and } 2 \text { nd economies }\end{array}$ & 2 \\
\hline Integrated planning through appropriate freight system intelligence & 2 \\
\hline
\end{tabular}

*1 = no progress; 2 = discussions; 3 = progress; 4 = significant progress 
It is evident that there has been limited implementation of the MSA and the NFLS. Subsequent to the NFLS, mode-specific road and rail strategies were released in 2011, but with a disconcerting lack of alignment. There is uncertainty about how these fit into the NFLS and concern about a continuous lag in implementation. In the following section, the causes of this implementation lag are discussed.

\section{DISCUSSION: OVERARCHING CHALLENGES IN GOVERNMENT'S ENABLEMENT OF LOGISTICS PERFORMANCE}

As discussed in the previous section, there is a significant gap between the visionary policies developed by the Department of Transport and the implementation of those policies. This is evidenced by the persistent macroeconomic logistics challenges reported in the introductory section. The critical role of national government in addressing these macroeconomic challenges was highlighted in the international overview on trade facilitation. The key impediment hampering the Department of Transport in executing this role, as revealed by the author's research, is fragmentation - of accountability (and subsequent human resource deployment), the strategic process (focusing mainly on policy development and not implementation), infrastructure investments and public-private interaction. These elements are now discussed in turn.

\section{Need for a single point of accountability}

The intention to address South Africa's freight logistics challenges has been on stakeholders' agendas since prior to the transition to democracy (DoT, 1996, 1998 and 2005; Mitchell, 2006: 1). While credit must be given for the strategic commitment, recent statements by both the Minister of Transport and the Minister of Public Enterprises confirm that, 15 years after the White Paper on National Transport Policy, the discussions on the table still revolve around many of the same issues, with little implementation evident, such as establishing an economic regulator for transport (Smith, 2011); reducing road congestion and addressing optimal modal balance (Naidoo, 2011); implementing the user-pay principle (Venter, 2011); and developing public-private participative investment models (Creamer, 2011a). While individual stakeholders have made some progress with implementation (refer to the section on infrastructure investment), a significant number of cross-functional issues exist (some of which have been mentioned previously) for which no aligned vision and therefore no implementation are visible. This points to two further issues. First, the number of stakeholders accountable for the country's logistics infrastructure (especially at this point in time) is too high, hampering policy implementation and sustainable infrastructure spending. Secondly, the skills shortage is exacerbated by the need for expertise to be spread across such a large number of stakeholders. 


\section{Numerous stakeholders accountable for the country's logistics infrastructure}

The DoT, Department of Public Enterprises (DPE), Transnet, the South African Roads Agency (SANRAL), and the Department of Trade and Industry (DTI) (among others) are all accountable for different elements of optimal national, cross-border and international freight logistics systems. Management theory clearly delineates between functional and cross-cutting (or process) management structures. The matrix or cross-functional team approach has been described by many management theorists, such as Hellriegel and Slocum (1996:523), who accentuate the competitive advantages of permanent cross-functional teams and the fact that problem-solving speed is accelerated with cross-functional integration. Stoner and Freeman (1989:413) point to innovation and that 'for innovation to be successful, a high degree of integration is required among the various units of the organization.' Pitts and Lei (2003:69-81) follow a value chain approach and provide a specific distinction between components of the chain and the integrative business system, which is essential for the creation of value.

The National Transport Master Plan project for the period 2005-2050 (Natmap) commissioned by the DoT also identifies 'the lack of integration in current infrastructure planning' and 'the fragmentation of roles and responsibilities of different planning authorities across the different spheres of government' as key impediments in integrated infrastructure planning (DoT, 2011a:8-2). In order to address these impediments, Natmap recommends, inter alia, 1) the creation of a National Transport Commission to advise the Minister of Transport and broaden the decision-making and policy-formulation process for freight transport to include the logistics providers and industrial users, and 2) reassigning the responsibility for freight transport policy in all modes to the Department of Transport and restructure the Department by functional responsibilities (DoT, 2011a:7-60). Within the DoT acknowledgement of this state of affairs is therefore growing, yet decisive action is still not evident.

\section{Skills shortage}

Although not the core focus of Natmap, several skills shortages across a broad spectrum of the logistics sector were identified during the course of the project including 1) for both ports and rail, failure to attract, train and develop adequate technical skills and management capacity in relation to sustainably meeting the national demand for freight transport; 2) the low level of skills in road maintenance and transport infrastructure development; 3) the shortage of technical skills to implement the Road Transport Quality System; and 4) insufficient road freight truck driver candidates (DoT, 2011a).

The systemic effect of this skills shortage is exacerbated by the need for expertise to be spread across the large number of entities mentioned earlier. 


\section{Need for aligned policy development with a non-negotiable implementation focus}

The main shift in focus from the DoT's MSA project (DoT, 1998) to the NFLS (DoT, 2005) was the NFLS' focus on institutional and policy reform required to implement logistics change in the country. What transpired, however, is another period of inaction that is now almost equal to the lapsed time between 1998 and 2005.

In addition, the DoT issued a Rail Policy Green Paper in May 2011 (DoT, 2011b), but no further discussion emerged from the process. Transnet developed a position paper on rail freight development at the same time, which was released to the DPE and DoT, but there is no evidence of integration between these two papers. A draft discussion document for the development of a road freight strategy was issued in June 2011 (DoT, 2011c), and the DPE also developed a strategic plan, both of which were developed in isolation and are not yet available for public comment.

An additional challenge is that the transition between different policies within and between government departments is not clear, hampering implementation efforts in both the public and private sectors. A clear policy transition would enable stakeholders to focus on relevant implementation actions.

Unfortunately, the outcomes of these documents are often a reiteration of the strategic actions in the White Paper (on National Transport Policy), the MSA and the NFLS. Identifying key implementation indicators of trade and logistics policies, rigorous tracking of these, and regular dissemination of the status quo are still absent.

\section{Fragmented infrastructure investments}

Transnet invested R53bn in its rail, port and pipeline businesses between 2008 and 2010, with another R93bn of investment planned between 2011 and 2015 (Transnet, 2010: 5, 20). Its investment planning is based on a 30-year demand forecast, and focuses on the development of the rail and port network in an integrated fashion (Transnet, 2009). However, Transnet does not occupy the institutional position to integrate transport investments for the entire logistics system of the country, nor the balance sheet strength required to fully align investment with demand. Government spent R70bn on provincial and national roads between 2008 and 2010, with another R88bn planned from 2011 to 2013 (SARF, 2010), and logistics service providers (LSPs) invest inter alia in warehousing, terminals, information technology and truck fleets. Aggregated investment data for LSPs is, unfortunately, not available, but the exponential growth in the road truck fleet illustrated in Figure 1 can be seen to indicate significant investment activity.

Unfortunately, very little alignment exists between the DoT, Transnet and LSP investment initiatives. This is extremely disconcerting, given the long life cycles of major logistics 
infrastructure investments, as illustrated in Figure 4. The planned significant investment levels are the optimal points at which to engineer a switch to more environmentally sustainable infrastructure options.

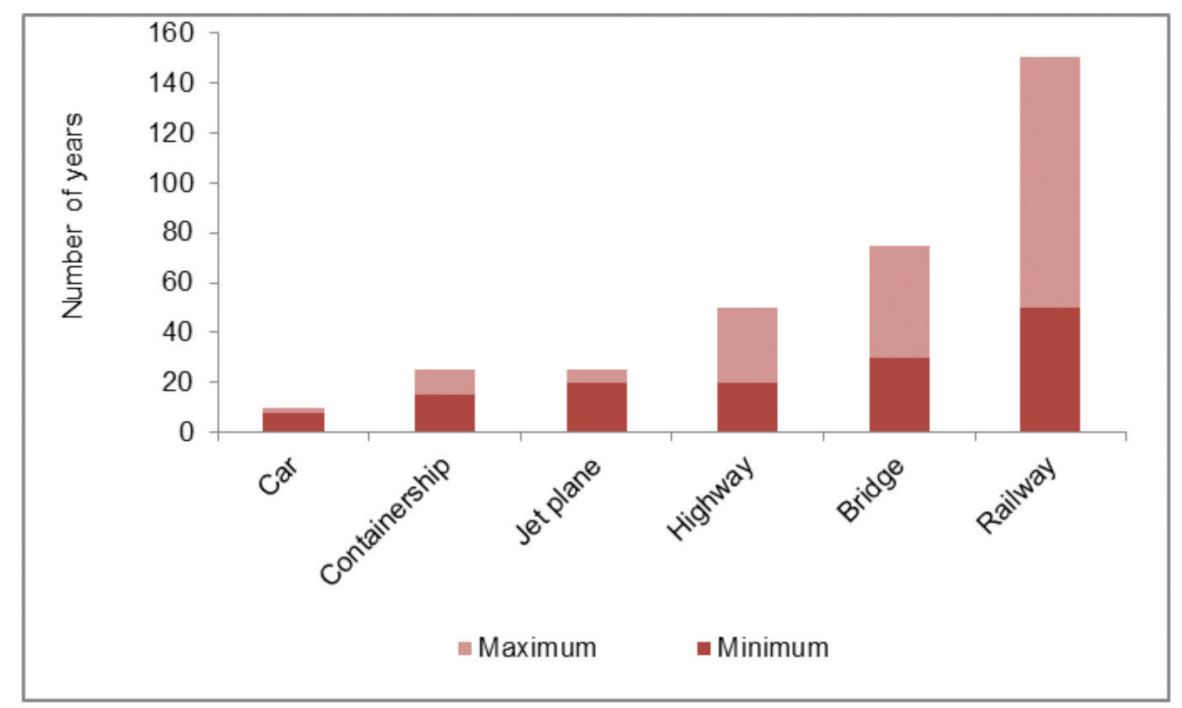

Figure 4: Lifespan of major transport assets (WWF, 2006)

The role and disposition of the private sector are also not facilitating integrated investments. Where representatives of the logistics industry are invited to participate in sessions where South Africa's freight logistics future is discussed, they often fail to submit visionary statements and provide leadership around an integrated solution for South Africa. Interaction with government at various forums frequently leads to lobbying of own interests for specific interest groups, rather than integrated solutions. Some exceptions do exist, such as statements on road-rail integration by Imperial Logistics (Imperial, 2010) and Unitrans (Grove, 2005).

The mid-2011 DoT investor conference explored, among others, freight logistics investment collaboration opportunities between government and the private sector, both here and abroad. This was a significant first step signalling not only the intent to collaborate between government entities (the Ministers of Transport, Tourism and Sport; Trade and Industry; and Public Enterprises were all present) but also between the private and public sectors (Business Day, 2011). While this is a very encouraging development, the conference did fall short of providing a long-term macroeconomic view of transport demand and how the identified projects fit into meeting this demand (DoT, 2011d). There is a significant risk that focuses on individual investment opportunities without concomitant transparent development, and tracking of the long-term macroeconomic goals of transport will ultimately reinforce the status quo. 


\section{Limited public-private collaboration}

Despite the integration challenges at government level, collaboration on a common theme is, however, possible, as indicated by the fledgling corridor approach. The successes identified on the Maputo Corridor (Freight into Africa, 2011) and the Gauteng-Durban corridor (Transnet, 2010: 43) confirm that an integrated approach is both possible and a requirement for success. Initial indications are that a corridor approach may lead to logistics efficiency through lower inventory levels (reducing financing charges and storage costs), freight consolidation and improved infrastructure utilisation.

Yet, to roll this out nationally will require integration between stakeholders. On government's side, all key stakeholders (i.e. the DoT, the DPE, the DTI and Transnet) have corridor strategies and resources allocated specifically to developing solutions. In the DoT's latest available annual report (DoT, 2009/10), one of the overarching strategic programmes listed is the Freight Logistics and Corridor Development Programme, with the responsibility to manage the implementation of the transport logistics strategy and the development of freight corridors. The DPE is developing national corridor performance measurement tools and indicators for improving efficiency and performance in the transport sector (DPE, 2011).

For the Southern African Development Community (SADC), a trans-national corridor approach also provides significant potential to address the high transport costs, poor infrastructure and inefficient cross-border processes that are challenging trade in many African countries. According to the Development Bank of Southern Africa (DBSA) (2008), one of the fundamental issues is that national rail routes in Africa appear to be too short to compete effectively against the new generation of road trucks. As in South Africa, the lack of progress in logistics planning in SADC is exacerbated by the numerous stakeholders with conflicting interests and a lack of sufficient skills.

In its latest annual report, Transnet (2010) confirmed its strategic focus on key corridors providing end-to-end logistics services to customers. The focused investment and development around key corridors is also one of the core tenets of Transnet's National Infrastructure Plan (Transnet, 2009). Additionally, there is currently a strong drive from the private sector to engage government and Transnet Freight Rail to develop domestic intermodal solutions tailor-made for corridors.

Freight logistics hubs are a fairly new phenomenon in South Africa and, while a number of hubs have been touted (for example, hubs in the Northern Province cities of Polokwane and Musina [Magagula, 2011] and in Gauteng's Rosslyn and at OR Tambo Airport [BuaNews, 2011]), progress in establishing these seems to be limited - this could be attributed to the fact the development of the hubs is independent of a holistic corridor view (going against the grain of an integrated hub-and-spoke system). (There are hub success stories, such as the progress made at the City Deep and Durban Container Terminals, facilitating efficiency 
improvements on the Gauteng-Durban corridor [Transnet, 2010], confirming the holistic corridor view.)

It is extremely challenging for industry to engage with government as a single entity and stakeholders are often forced to engage with individual government departments and stateowned entities (SOEs). Public-private partnerships are being suggested, but are difficult to implement due to the poor balance sheets of SOEs, and government inertia.

\section{Regional considerations}

In terms of South Africa's role in the broader region, the major issue is the highly skewed nature of the relationship in South Africa's favour. South Africa contributes $60 \%$ of both the SADC's GDP and imports, and 50\% of exports (CIA, 2008). In addition, the SADC member states are highly dependent on their trade with South Africa, with a very high percentage of imports coming from South Africa, ranging from 37\% for Mozambique to $85 \%$ for Namibia and Botswana. Similarly, a high percentage of most of the exports of SADC countries go to South Africa, ranging from 7\% for Botswana to 34\% for Zimbabwe. In contrast, South Africa is less dependent on the region, with only $9.3 \%$ of its exports going to SADC and $5.4 \%$ of its imports coming from SADC (CIA, 2008).

Low intra-regional trade (see Table 4) is also a challenge within all of Africa's regional economic communities compared with trade with non-African regional blocks, and is further confirmation that regional integration is not making progress.

Table 4: Low trade shares between regional economic communities in Africa* (percentages) (Atta-Mensah, 2008)

\begin{tabular}{|l|c|c|c|c|c|}
\hline & Intra-REC & Rest of Africa & EU & US & Others \\
\hline CEMAC & 1.9 & 2.2 & 41.2 & 30.5 & 24.2 \\
\hline COMESA & 6.0 & 8.2 & 39.3 & 20.8 & 25.7 \\
\hline EAC & 18.1 & 12.4 & 40.5 & 3.6 & 25.4 \\
\hline ECCAS & 1.9 & 2.5 & 45.2 & 27.7 & 22.8 \\
\hline ECOWAS & 10.3 & 2.9 & 39.0 & 26.1 & 21.8 \\
\hline SADC & 12.8 & 4.6 & 26.6 & 14.0 & 42.0 \\
\hline Africa & 6.8 & 5.8 & 49.7 & 15.1 & 22.7 \\
\hline
\end{tabular}

*Regional economic communities in Africa:

\begin{tabular}{|l|l|}
\hline CEMAC & Economic and Monetary Community of Central Africa \\
\hline COMESA & Common Market for Eastern and Southern Africa \\
\hline EAC & East African Community \\
\hline ECCAS & Economic Community of Central African States \\
\hline ECOWAS & Economic Community Of West African States \\
\hline
\end{tabular}


In addition, transport and insurance costs as a percentage of trade value are on average around $20 \%$ for sub-Saharan African (SSA) landlocked countries compared with 5\% for OECD countries (Organisation for Economic Co-operation and Development) (De Bod, 2008). This significantly impacts on the competitiveness of SSA exports and also impacts on the costs of imports and, therefore, the prices of goods in the local market.

Regional integration is further constrained by a confusing array of regional configurations and trade agreements. SSA's overlapping regional integration configurations form a complex web of interests (Warin, Wunnava, Tengia \& Wandschneider, 2009: 2). African states need to work actively towards an integrated regional approach - as attempted with the new African tripartite free trade area (Creamer, 2011b) - and the international community needs to act accountably in its interaction with the region. For example, according to Atta-Mensah (2008), the EU was able to secure at least one agreement in each regional configuration in Africa, with more in some, but did not necessarily include all members of the regional configuration.

This state of affairs, together with South Africa's internal challenges, will inevitably influence the practical priority given to resolving SADC trade issues relative to international trade issues. Discussions with major players suggest that cross-border logistics issues are understood, but these never make it to the top of the list in terms of priorities. When crossborder issues do come into play, they are viewed in terms of the logistics infrastructure that will benefit South Africa, for example, the Maputo corridor and, over the longer term, the Trans-Kalahari corridor, which will give Gauteng more access options. In a recent study conducted for government, senior industry executives generated nine items in focus groups that describe Transnet's desired role in the economy (Havenga, De Bod \& Aucamp, 2009). In the subsequent quantitative survey, 'contribution to the SADC network' (one of the nine statements) received the lowest importance rating.

Further obstacles to integration are the contradictory nature of domestic production, poor infrastructure linkages, a lack of enforcement of regional protocols, sovereignty, prohibitive customs and border controls, and a lack of international trade financing. The status quo is, therefore, fragmented markets and industries, where individual countries are constrained by the small size of their economies (Manuel, 2006).

\section{CONCLUSION AND RECOMMENDATIONS}

International research emphasises that the drivers of trade facilitation are the establishment and maintenance of an integrated competitive national freight logistics system enabled by a high level of collaboration between supply chain stakeholders in both the public and private sectors (refer to Figure 5). These drivers are summarised as follows: 
- An integrated logistics system implies policy certainty and efficient road and rail networks, connected to logistics hubs. In import and export locations, the ports are integrated with the logistics hubs. Included in logistics hubs are warehousing and distribution infrastructures. The system is supported through effective ICT, with software that optimises the flow of commodities and the level of inventory throughout the chain.

- A high level of supply chain collaboration implies co-operation within industries, across industries, across regions and through the supply chain, in order to optimise the use of infrastructure and to manage inventory levels throughout the supply chain.

On a macroeconomic level, the typical progress on the matrix normally involves industry focusing on increasing the level of supply chain collaboration, with government focusing on integration of the national logistics system.

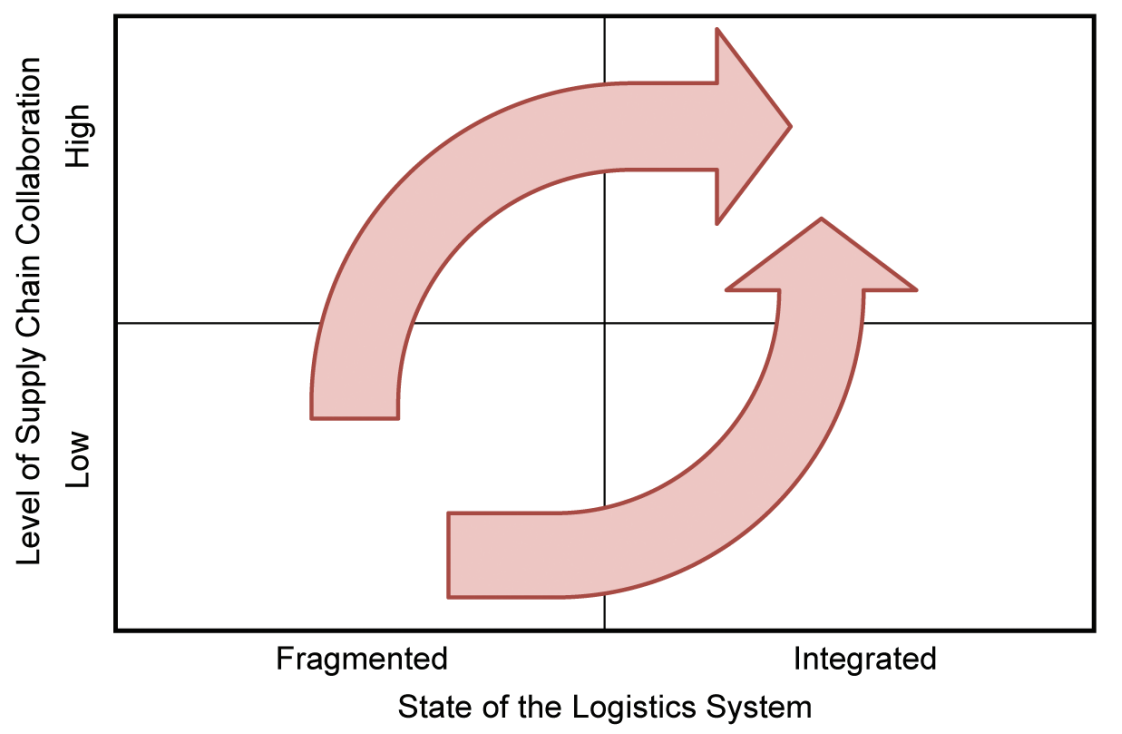

Figure 5: Drivers of competitive supply chains

As mentioned in the section on policy, little tangible implementation of the White Paper (on National Transport Policy), the MSA or the NFLS has been experienced, and this has been followed by the release of more (unaligned) mode-specific policies in 2011.

Between the MSA and the NFLS, the concepts of supply chain collaboration and systemic logistics integration are, however, addressed. The implementation initially focused on addressing the challenges in the various transport modes, with integration of the logistics system falling by the wayside due to the short-term pressures resulting from the aforementioned challenges (see Figure 6). 


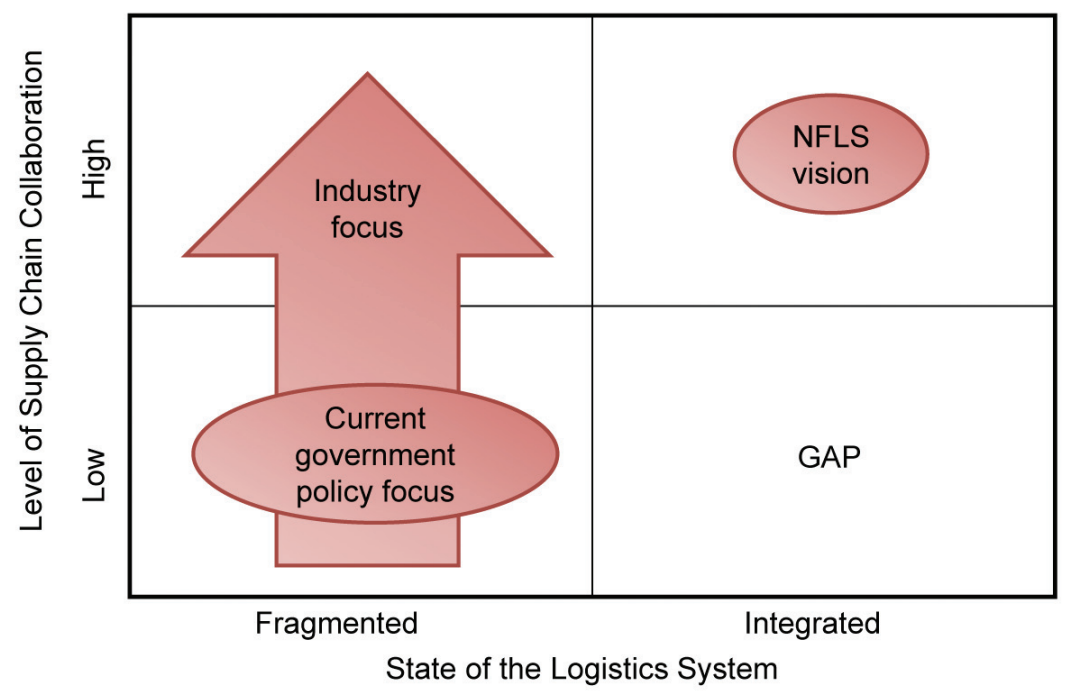

Figure 6: Drivers of competitive supply chains - applied to South Africa

The optimal way for South Africa and the broader region to implement the required changes in an effective and timely manner is for accountability for the logistics system to lie with a single entity.

In order to develop a way forward, insight is drawn from the case study on the Dayton agreement of 1995 that ended the Bosnian War. According to Camisar, Diechtiareff, Letica and Switzer (2005: 6-8) 'in the Bosnian case, the large number of parties involved, along with the diversity of issues to be addressed, meant that structural complexity represented a clear barrier to a negotiated agreement'. Accountability was given to a single individual (Richard Holbrooke) to solve the crisis expeditiously. He delivered this by, first, simplifying the issues through thorough preparation and keeping a record of the proceedings for reference purposes. Secondly, he developed overarching themes that everybody could identify with around what was really important. Thirdly, he was supported in the process by everybody who really mattered being present, and he was given three weeks in a remote environment to complete the job. Finally, no media were allowed, which made it unnecessary for the parties to posture around constituent issues (Freeman, 1997). As aptly summarised by Bardos (2011), 'Holbrooke was probably right to boast about ... the most successful peace agreement of the last generation. It ended 43 months of war and paved the way for what is arguably the most successful refugee return program in history - all at the cost of zero American lives lost to hostile fire.'

The Dayton success recipe is possible in South Africa. The single accountable individual should be the Minister in the Presidency for National Planning. He could call together the triumvirate of responsible government ministers - the respective Ministers of the DPE, the DoT and the DTI. Core players from the DoT, the DPE, the DTI, SANRAL, Transnet and organised industry should be invited, and it should include not only the 'politicians' in each 
organisation, but also the strategic thinkers and implementers among the rank-and-file personnel. Once the final group has been established, attendance should be compulsory. An important rule would be that nobody in his or her personal capacity be allowed to attend 'piecemeal', i.e. join the proceedings late or leave early. The proceedings should be arranged at a location with no distractions, and should involve a two- to three-week indaba where all the issues are recorded, and then streamlined into overarching themes (which can be arrived at through widely available strategic planning techniques). The goal should be to develop the real logistics requirement for South Africa, based on available 30-year demand research. From this, the broad framework for implementation should be developed, and finally, mode-specific strategies (road, rail and ports), transport economic regulation and institutional arrangements have to be linked to the broad framework. The Minister in the Presidency for National Planning would drive implementation through the triumvirate of the responsible government ministers. This sequence of events would be possible if the political will truly exists to prepare the country's logistics infrastructure for the future. The success of this type of approach has been demonstrated in Singapore's 'communitarian democracy', where benevolent paternalism has advanced economic development and socio-political stability (Caoili, 2005).

The alternative is for the above approach to be effected by the newly established Presidential Infrastructure Coordinating Commission that has the mandate 'to provide oversight, monitor and ensure speedy delivery of infrastructure projects around the country' (The Presidency, 2011). According to the press release, the DoT and Transnet are however not represented on the Management Committee (Creamer, 2011c). Given the national importance and scale of freight logistics infrastructure investment, this is an oversight that serves to confirm the concerns expressed in this article. 


\section{REFERENCES}

Atta-Mensah, J. 2008. Economic Partnership Agreements: Regional Integration in Africa, the Rationalization of RECs and Economic Partnership Agreements. Addis Ababa: UN Economic Commission for Africa.

Bardos, G.N. 2011. In defense of Richard Holbrooke. Eurasia Review, March 2011.

BuaNews. 2011. Gauteng to create thousands of job opportunities. BuaNews, 21 February 2011. Available from: www.buanews.gov.za/news/11/11022113351002 (Accessed 20 July 2011).

Business Day. 2011. Transport investment - Transport investor conference. Available from: www.businessday.co.za/Articles/Content. aspx?id=146589 (Accessed 2 October 2011).

Camisar, A., Diechtiareff, B., Letica, B. \& Switzer, C. 2005. An analysis of the Dayton negotiations and Peace Accords. Medford: The Fletcher School of Law \& Diplomacy.

Caoili, R. 2005. Reflections on democracy and development in Southeast Asia: Why do the Philippines and Singapore differ? Culture Mandala: The Bulletin of the Centre for East-West Cultural and Economic Studies, 6(2): Article 1.

Christ, N. \& Ferrantino, M.J. 2011. Land transport for export: The effects of cost, time and uncertainty in Sub-Saharan Africa. World Development. 39(10):1749-59.

CIA. 2008. World Factbook. Available from: https://www.cia.gov/library/publications/theworld-factbook/ (Accessed 25 July 2011).

Creamer, T. 2011a. Task team interrogates resources-linked infrastructure needs. Engineering News. 9 May 2011.

- 2011b. Cameron promises practical support for Cape-to-Cairo trade bloc vision. Engineering News. 18 July 2011.

- 2011c. Engineers called upon to bolster Zuma's infrastructure commission. Engineering News. 22 September 2011.

DBSA (Development Bank of Southern Africa). 2008. Infrastructure Barometer 2008. Available from: www.dbsa.org/feature/pages/default.aspx (Accessed 20 July 2011). 
De Bod, A. 2008. South Africa's freight transport involvement options in Sub-Saharan Africa: Declining infrastructure and regulatory constraints. Unpublished master's thesis. Stellenbosch: University of Stellenbosch.

De Sousa, D. \& Findlay, C. 2007. Relationship between liberalization in the logistics sector and trade facilitation. New York: United Nations.

De Villiers, W.J. 1986. Strategic planning, management practices and systems of the South African Transport Services. Pretoria: South African Transport Services.

DoT (National Department of Transport, South Africa). 1996. White Paper on National Transport Policy. Pretoria: Department of Transport.

- 1998. Moving South Africa: A Transport Strategy for 2020. Pretoria: Department of Transport.

- 2005. National Freight Logistics Strategy. Pretoria: Department of Transport.

- 2009/10. Annual Report. Pretoria: Department of Transport.

- 2011a. National Transport Master Plan - Phase 3: Forward planning. Available from: www.transport.gov.za/siteimgs/NATMAP\%20Summit\%20Presentation/NATMAP\%20Draft/ NATMAP\%202050\%20-\%20Phase\%203\%20May\%202011.pdf (Accessed 2 October 2011).

- 2011b. Rail Policy Green Paper. Unpublished. Pretoria: Department of Transport.

- 2011c. Draft discussion document - Road Freight Strategy. Unpublished. Pretoria: Department of Transport.

- 2011d. Department of Transport International Investor Conference - Strategic Transportation Projects. 13-14 June 2011. Available from:

www.dotinvestorsconference.co.za/img/DOT_Investor_Conference_Book.pdf (Accessed 2 October 2011).

DPE(Department ofPublic Enterprises, South Africa). 2011. TransportEnterprises: Measurable objectives. Available from: www.dpe.gov.za/programmes-2_transportenterprises (Accessed 22 July 2011).

Edwards, L. 2006. Has South Africa liberalised its trade? Southern Africa Labour and Development Research Unit. Cape Town: University of Cape Town. 
- 2008. Trade, trade policy and growth in South Africa. Cape Town: University of Cape Town.

Edwards, L. \& Lawrence, R. 2006. South African Trade Policy Matters: Trade Performance \& Trade Policy. Centre for International Development. Cambridge: Harvard University.

eNatis (electronic National Traffic Information System). 2011. Available from: www.enatis. com (Accessed 25 July 2011).

Freeman, B. 1997. The Road to Dayton: US Diplomacy and the Bosnian Peace Process. Washington: United States Department of State.

Freight into Africa. 2011. The Maputo Corridor. 6 July 2011. Available from: www. freightintoafrica.co.za/news/368-the-maputo-corridor (Accessed 25 July 2011).

Grove, J. 2005. Chief Executive's Report, Unitrans Limited Annual Report. Johannesburg: Unitrans Limited.

Havenga, J.H. 2007. The development and application of a freight transport flow model for South Africa. Unpublished doctoral thesis. Stellenbosch: University of Stellenbosch.

- 2010. Logistics costs in South Africa - The case for macroeconomic measurement. South African Journal of Economics. 78(4):460-78.

Havenga, J.H., De Bod, A. \& Aucamp, P. 2009. The effect of Transnet on the economy. Unpublished report. Pretoria: the Department of Public Enterprises.

Havenga, J.H., Pienaar, W.J. \& Simpson. Z. 2011. A case for measuring logistics costs on a national level: a South African application. Corporate Ownership \& Control. 8(3):622-31.

Havenga, J.H., Simpson, Z. \& Fourie, P. 2011. Unpublished freight transport demand model developed for Transnet. Durbanville: Growth and Intelligence Network.

Hellriegel, D. \& Slocum, J.W. 1996. Management. 7th ed. Cincinnati: South-Western College Publishing.

Ikenson, D. 2008. While Doha sleeps: Securing economic growth through trade facilitation. London: International Policy Network.

Imperial. 2010. Inter-modal logistics solutions key to driving regional competitiveness. Available from: www.imperiallogistics.co.za/news/regional-competitiveness/ (Accessed 24 July 2011). 
Isemede, J.O. 2011. The role of organized private sector in trade facilitation: Achievements, challenges \& way forward'. The Nigerian Association of Chambers of Commerce, Industry, Mines and Agriculture. Available from: www.nigerianexporter.org/downloads/ NACCIMA\%2OPRESENTATION\%20AT\%20NITPRO\%20WORKSHOP\%2020TH-21ST\%20 JAN\%202011\%20\%5BCompatibility\%20Mode\%5D.pdf (Accessed 2 October 2010).

Korinek, J. \& P. Sourdin. 2011. To what extent are high-quality logistics services trade facilitating?, OECD Trade Policy Working Papers, No. 108, OECD Publishing.

Jenkins, C., 2001. Integration and cooperation in Southern Africa. Working paper no.172. Paris: OECD Development Centre.

Magagula, Z. 2011. Limpopo road building for young people. 27 Feb 2011. Available from: m.news24.com/news24/SouthAfrica/Politics/Limpopo-road-building-for-young-people20110227 (Accessed 26 July 2011).

Manuel, T. 2006. Opening Remarks for the ICM. SADC Integrated Committee of Ministers. 22 June 2006. Available from: www.dfa.gov.za/docs/speeches/2006/manu0622.htm (Accessed 20 July 2011).

Mitchell, M. 2006. Confronting land freight challenges in South Africa. Available from: www. sarf.org.za/news/30_Land\%20freight\%20issues\%20web.doc (Accessed 23 July 2011).

Musonda, C.M. 2005. Private Sector Role in Intra-Africa Trade \& Trade Facilitation. Private Sector \& Trade Development Zambia. Available from: www.uneca.org/eca_programmes/ trade_and_regional_integration/meetings/addis/intraregionaltrade/Private\%20sector\%20 presentation.ppt (Accessed 2 October 2011).

Naidoo, B. 2011. TPT starting to see benefits of Cape Town container upgrade. Engineering News. 6 May 2011.

Oosterhaven, J. \& Rietveld, P. 2005. Transport costs, location and the economy, in Brakman, S. \& Garretsen, H., eds. Location and Competition. London: Routledge.

Pitts, R.A. \& Lei, D. 2003. Strategic Management: Building and sustaining competitive advantage. Mason: Thompson.

Portugal-Perez, A. \& Wilson, J.S. 2009. Why trade facilitation matters to Africa. World Trade Review. 8(3):379-416. 
The Presidency. 2011. Presidential Infrastructure Coordinating Commission to meet. 7 September 2011. Available from: www.thepresidency.gov.za/pebble.asp?relid=4810 (Accessed 2 October 2011).

SARB (South African Reserve Bank). 2009. Historical macroeconomic time series information. Available from: www.reservebank.co.za (Accessed 26 July 2011).

SARF (South African Road Federation). 2010. A review of the South African road network and its impact on the bituminous product industry. Available from: sarf.org.za/data-research/ SA\%20Roads\%20Review\%20Revised\%20January\%202010v2.pdf (Accessed 20 July 2011).

Smith, N. 2011. New transport regulator to boost investment. Business Day. 14 June 2011. Pretoria: BDFM Publishers (Pty) Ltd.

Stander, H.J. \& Pienaar, W.J. 2005. Land freight issues in South Africa. The 24th annual Southern African transport conference. Pretoria. 11-13 July 2005.

Stoner, J.A. \& Freeman, R.E. 1989. Management. 4th ed. Englewood Cliffs: Prentice-Hall International Holdings.

Theron, J., Godfrey, S. \& Visser, M. 2007. Globalization, the impact of trade liberalization, and labour law: The case of South Africa. Geneva: International Institute for Labour Studies.

Trading Economics. 2011. Merchandise trade (\% of GDP) in World. Available from: www. tradingeconomics.com/world/merchandise-trade-percent-of-gdp-wb-data.html (Accessed 21 July 2011).

Transnet. 2009. National Infrastructure Plan. Available from: www.transnet.co.za/ BusinessWithUs/TNIfraPlans.aspx (Accessed 24 July 2011).

- 2010. Annual Report. Johannesburg: Transnet Limited.

Transnet Freight Rail. 2011. Historical data on number of wagons and locomotives obtained from Transnet Freight Rail. Johannesburg: Transnet Limited.

UNCTAD. 2006. Trade facilitation handbook Part I - National Facilitation Bodies: Lessons from Experience. Available from: www.unctad.org/en/docs/sdtetlb20051_en.pdf (Accessed 29 September 2011). 
- 2010. Engaging the trading community - Forum on WTO, trade facilitation and the private sector in developing countries. Available from: www.gfptt.org/uploadedFiles/ d5b782be-9746-400c-b857-a1eac4aee4a5.pdf (Accessed 2 October 2010).

Venter, I. 2011. Transport society voices support for user-pays principle. Engineering News. 8 July 2011.

Warin, T., Wunnava, P.V., Tengia, O., Wandschneider, K. 2009. Southern African Economic Integration: Evidence from an Augmented Gravity Model. Bonn: The Institute for the Study of Labor (IZA).

Weerahewa, J. 2009. Impact of trade facilitation measures and regional trade agreements on food and agricultural trade in South Asia. Asia-Pacific Research and Training Network on Trade Working Paper Series, No 69, June 2009.

Wesgro. 2010. Logistics sector fact sheet. Available from: http://www.wesgro.co.za/ publications/files/useruploads/user_anon/files/Logistics.pdf (Accessed 24 July 2011).

Wilson, J.S., Mann, C.L. \& Otsuki, T. 2003. Trade facilitation and economic developmentMeasuring the impact. The World Bank Development Research Group

March 2003. Policy research working paper 2988.

Wilson, R. 2010. 21st Annual State of Logistics Report. Washington DC: Council for Supply Chain Management Professionals.

- 2011. 22nd Annual State of Logistics Report. Washington DC: Council for Supply Chain Management Professionals.

World Bank, 2010. Connecting to compete: Trade logistics in the global economy. Available from: www.worldbank.org/lpi (Accessed 26 July 2011).

WTO Ministerial, 1996. Singapore Ministerial Declaration adopted on 13 December 1996. Available from: www.wto.org/english/thewto_e/minist_e/min96_e/wtodec_e.htm\#trade_ facilitation (Accessed 27 September 2011).

WTO. 2011a. Understanding the WTO: Cross-cutting and new issues. Available from: www. wto.org/english/thewto_e/whatis_e/tif_e/bey3_e.htm (Accessed 27 September 2011). 
- 2011b. The European Union offers EUR180,000 to the WTO development fund for trade facilitation. Available from: http://www.wto.org/english/news_e/pres11_e/pr639_e.htm (Accessed 27 September 2011).

WWF (World Wildlife Fund). 2006. Living Planet Report. Gland: WWF International.

\section{Table of acronyms}

\begin{tabular}{|l|l|}
\hline APEC & Asia Pacific Economic Cooperation \\
\hline DBSA & Development Bank of Southern Africa \\
\hline DoT & Department of Transport \\
\hline DPE & Department of Public Enterprises \\
\hline DTI & Department of Trade and Industry \\
\hline ETI & Enabling Trade Index \\
\hline GDP & Gross Domestic Product \\
\hline ICT & Information and Communications Technology \\
\hline LPI & Logistics Performance Index \\
\hline LSP & Logistics Service Providers \\
\hline MSA & Moving South Africa \\
\hline Natmap & National Transport Master Plan \\
\hline NFLS & National Freight Logistics Strategy \\
\hline OECD & Organisation for Economic Co-operation and Development \\
\hline SADC & Southern African Development Community \\
\hline SANRAL & South African Roads Agency \\
\hline SARB & South African Reserve Bank \\
\hline SARF & South African Road Federation \\
\hline SOE & State-Owned Entity \\
\hline SSA & Sub-Saharan Africa \\
\hline WTO & World Trade Organisation \\
\hline WWF & World Wildlife Fund \\
\hline
\end{tabular}

